УДК 378.147:004:811.112.2’342

Бескорса Олена Сергї̈вна

кандидат педагогічних наук, старший викладач кафедри теорії і практики початкової освіти ДВНЗ «Донбаський державний педагогічний університет», м. Слов’янськ, Україна

ORCID ID 0000-0001-8018-8549

beskorsyhelen@gmail.com

\title{
СИСТЕМА МООDLЕ ЯК ЗАСІБ ОРГАНІЗАЦІЇ ЗМІШАНОГО НАВЧАННЯ ПРАКТИЧНОЇ ФОНЕТИКИ НІМЕЦЬКОЇ МОВИ
}

\begin{abstract}
Анотація. У статті йдеться про організацію змішаного навчання дисципліни «Практична фонетика німецької мови» у віртуальному навчальному середовищі Moodle. Автором узагальнено передовий досвід вітчизняних і західних дослідників із питань упровадження змішаного навчання й технології розроблення дистанційних курсів у віртуальному навчальному середовищі Moodle. Зазначено, що специфіка вправ із практичної фонетики полягає в тому, що вони мають містити завдання на запис власного голосу, для оцінювання рівня сформованості слухо-вимовних і ритміко-інтонаційних навичок мовлення. Автор описує власний досвід упровадження дистанційного курсу в навчання фонетики студентів напряму підготовки «Початкова освіта». Запропонований автором курс містить вісім тем, кожна тема передбачає виконання завдань у трьох блоках - теоретичному, практичному, комунікативному. У статті представлено дані експериментальної перевірки впроваджуваного курсу, які підтверджують його ефективність.
\end{abstract}

Ключові слова: практична фонетика; німецька мова; фонетична компетентність; ритмікоінтонаційні навички; слухо-вимовні навички;віртуальне навчальне середовище; Moodle; змішане навчання.

\section{1. ВСТУП}

Постановка проблеми. Соціально-економічні й культурні зміни, що відбуваються в суспільстві на сучасному етапі його розвитку, значну увагу привертають до збереження і розвитку європейської культурної та мовної спадщини. Відтак у загальноосвітніх навчальних закладах учні вивчають дві іноземні, переважно європейські мови й особливого значення набуває вивчення німецької мови. Невипадково учні обирають німецьку мову для вивчення як другу іноземну, адже, поперше, Німеччина посідає провідне місце серед європейських країн, які пропонують низку культурних та освітніх програм для активної молоді, по-друге, німецька мова $є$ державною в ФРН, Австрії, Швейцарії, Ліхтенштейні та Люксембурзі, тобто майже четверта частина всього населення Свропи є німецькомовною. Не виключено, що німецька мова може бути першою іноземною мовою, яка вивчається з першого класу початкової школи. Тому з метою надання базових знань й оволодіння елементарними практичними вміннями й навичками спілкування німецькою мовою до навчальних планів підготовки студентів рівня вищої освіти «Бакалавр» спеціальності 013 «Початкова освіта», спеціалізації «Англійська мова» введено вибіркові дисципліни «Практична фонетика німецької мови», «Практична граматика німецької мови», «Практика усного та писемного мовлення (німецька мова)».

Навчальна дисципліна «Практична фонетика німецької мови» вивчається на другому курсі та $є$ вступним курсом вивчення німецької мови, у якому закладаються базові основи практичного володіння іноземною мовою. Метою вивчення дисципліни $\epsilon$ засвоєння фонетичного матеріалу й комплексне формування рецептивних i продуктивних слухо-вимовних та ритміко інтонаційних навичок. 
Слід також зазначити, що під час визначення головної практичної мети вивчення іноземної мови увагу перенесено з викладання граматично правильного мовлення на навчання виразного й ефективного мовленнєвого спілкування, що обумовлено змінами в підходах до викладання іноземної мови, оновленням змісту й методів навчання. У цьому контексті особливого значення набуває сформованість у мовців слухо-вимовних ритміко-інтонаційних навичок.

На вивчення дисципліни відведено 150 годин, з них 80 годин аудиторної роботи та 70 годин самостійної роботи. Процес формування фонетичних навичок не може відбуватися поза видами мовленнєвої діяльності (говоріння, читання, письмо, аудіювання), вимова як матеріальний вияв мови $є$ основою всіх видів мовленнєвої діяльності. Такої кількості контактних годин не вистачає для формування слуховимовних та ритміко-інтонаційних навичок усіх видів мовленнєвої діяльності. Раціональним вирішенням проблеми формування фонетичної компетентності $\epsilon$ створення дистанційного курсу «Практична фонетика німецької мови» на платформі Moodle, що дозволяе використовувати різні прийоми й методи опрацювання навчального матеріалу та структурувати самостійне навчання студентів.

Аналіз останніх досліджень і публікацій. Загальні аспекти формування фонетичної компетентності в методиці навчання іноземних мов висвітлені в працях Н. Бориско (формування фонетичної компетентності учнів початкової школи), А. Долиної (формування фонетичної компетентності у майбутніх учителів англійської мови), С. Ніколаєвої, А. Хомутової (визначення структури та змісту фонетичної компетентності), О. Тарнопольського та ін. [1; 2; 3]. О. Старинець, О. Гуслистий у своїх дослідженнях вивчають проблеми навчання іноземної мови, зокрема навчання вимови на початковому етапі вивчення німецької мови як другої іноземної [4].

Проблемою становлення дистанційної освіти та технологій розроблення дистанційних курсів в Україні займаються А. Аврамчук, В. Кухаренко, I. Ковалинськата інші[5; 6; 7]. С. Долинський, О. Дмітрієва, вивчають методичні аспекти вивчення іноземної мови через мережу Інтернет [8]. А. Томіліна докладно вивчає можливості розроблення дистанційних курсів із практичного курсу англійської мови на базі електронної платформи Moodle [9]. Н. Майер доводить, що система Moodle може бути доцільно використана для створення «електронного кейсу» для самостійного вивчення іноземних мов. Учена розробила структуру і представила зміст електронного кейсу для розвитку вмінь ділового письма й умінь читання [10].

М. Ешбі (M. Ashby) [11] досліджує питання досягнення інтерактивності в дистанційних курсах, що мають на меті формування слухо-вимовних та ритмікоінтонаційних навичок. Він разом із групою дослідників розробили дистанційний курс «Phonline», упровадження якого дозволило провести дослідження ефективності протоколу голосового Інтернет зв'язку (VoIP - VoiceOverInternetProtocol) у віртуальному навчальному середовищі(VLE - VirtualLearningEnvironment). Moodle $\epsilon$ віртуальним навчальним середовищем, яке дозволяє обмінюватися файлами мультимедія, прикріпленими до повідомлень на форумі або в розділі виконання практичних завдань, який супроводжується оцінюванням. Однак, на думку М. Ешбі,цей процес є занадто складним. У своєму проекті він також оцінив можливості використання Skype зв'язку як засобу навчання практичної фонетики й оцінювання слухо-вимовних та ритміко-інтонаційних навичок. Результативність процесу формування фонетичної компетентності може бути досягнуто за умови регулярного інтернет-зв'язку через будь-яку систему голосового зв'язку, незалежно від того, чи вона $\epsilon$ автономною або інтегрованою у віртуальне навчальне середовище. М. Ешбі також запропонував ієрархію рівнів інтерактивності дистанційного курсу. Нульовий рівень інтерактивності - це наявність у дистанційному курсі лекцій, онлайн ресурсів, 
які можуть бути завантажені; перший рівень інтерактивності досягається за умови, якщо студент може обирати завдання, регулювати швидкість їх виконання і кількість спроб і повторень; другий рівень - студенти можуть ставити запитання іншим студентам та викладачеві; третій рівень реалізується через визначення потреб студентів за моделями його поведінки й відповідями у віртуальному освітньому середовищі [11].

К. де Брейн (Ch. de Bruijn), М. Б. Нунс(М. В. Nunes) [12] та інші дослідники 3 Великої Британії створили дистанційний курс для самостійного навчання практичної фонетики англійської мови, який дозволяє студентам створювати власні вправи із запропонованих записів відповідно до їхніх навчальних потреб. На аудіозаписах студентам доступні окремі фонеми, англійські слова, слова нонсенси та короткі фрази.

Однак, з-поміж значної кількості наукових досліджень у галузі вивчення іноземних мов із використанням ресурсів Інтернету, а також технології розроблення дистанційних курсів, у сучасній методичній науці досвід створення дистанційних курсів для вивчення німецької мови в цілому є незначним, особливо із використанням системи Moodle для формування ритміко-інтонаційних навичок німецького мовлення.

Мета статті - теоретично обгрунтувати та описати власний практичний досвід розроблення дистанційного курсу «Практична фонетика німецької мови» на базі платформи Moodle з метою формування німецькомовної фонетичної компетентності майбутніх учителів початкової школи.

\section{2. МЕТОДИ ДОСЛІДЖЕННЯ}

У нашому дослідженні було використано такі методи: метод аналізу й узагальнення наукової літератури 3 теорії і методики навчання німецької мови (Н. Бориско, А. Долина, А. Хомутова) [1; 2; 3], а також 3 теорії та практики впровадження змішаного навчання в організацію самостійної й аудиторної роботи студентів вищих навчальних закладів (К. Бугайчук, В. Кухаренко, Т. Примак, Л. Пузейкина) [6; 13; 14]. Для виявлення ефективності розробленої системи вправ із формування слуховимовних та ритміко-інтонаційних навичок німецького мовлення майбутніх учителів початкової школи було використано метод тестування, методи інтерпретації, узагальнення і репрезентування власних результатів дослідження.

\section{3. РЕЗУЛЬТАТИ ДОСЛІДЖЕННЯ}

Навчальна дисципліна «Практична фонетика німецької мови» є вступним курсом, який має на меті, як уже зазначалося, формування слухо-вимовних і ритмікоінтонаційних навичок німецької мови, що складають зміст фонетичної компетентності майбутніх учителів іноземної мови в початковій школі.

Ураховуючи специфіку навчальних планів і той факт, що ця дисципліна є єдиною в галузі вивчення німецької мови, ми вважаємо, що студенти мають оволодіти певною кількістю лексичних одиниць і граматичних структур, що відповідають рівню А2 (Grundstufe - Anfänger) відповідно до Загальноєвропейських рекомендацій з мовної освіти. Засвоєння фонетичного, лексичного та граматичного матеріалу має забезпечувати комунікативну діяльність студентів у ситуаціях спілкування, функціональний характер засвоєння і використання мовних засобів. На відміну від граматичних і лексичних навичок, формування фонетичних навичок $є$ більш складним процесом, який вимагає високого рівня автоматизації, тобто володіння фонетичними нормами іноземної мови на інтуїтивному (несвідомому) рівні (О. Старинець, О. Гуслистий), щоб мінімізувати міжмовну інтерференцію, небажаний вплив рідної або 
першої іноземної мови. Дослідження в галузі риторики й культури мовлення засвідчують, що феномен впливу на фонетичний аспект виучуваної іноземної мови виявляється не лише на рівні звуків, але й на рівні складу, наголосу, ритму, інтонації [4]. Порушення ритму мовлення й інтонації мають більше негативного впливу на розуміння мовлення, на реалізацію комунікативних типів висловлювань (розповідного, питального, спонукального), передавання емоційного ставлення мовця до повідомлюваної інформації, ніж некоректне вимовляння окремих звуків i звукосполучень.

Дистанційний курс розроблено виходячи 3 основних завдань навчальної дисципліни: формування нормативної (апроксимованої) вимови; розвиток фонематичного й інтонаційного слуху; сприймання зв'язного мовлення 3 метою визначення функціональних типів речення, емоційного і стилістичного забарвлення текстів різного типу; уміння вживати різні ритміко-інтонаційні моделі у власному мовленні з метою емоційного і стилістичного забарвлення текстів різного типу; уміння кодувати й декодувати лексичні одиниці і речення (ритміко-інтонаційні групи) за допомогою графічних схем (інтонограм); сприяння розширенню філологічного кругозору студентів через певний мінімум теоретичних знань у галузі практичної фонетики і фонології німецької мови. Навчальне середовище Moodle дає можливість реалізувати принцип комунікативності у навчанні іноземної мови через такі механізми: перцептивний (сприйняття навчальної інформації через аудіовізуальний канал); інтерактивний (організація іншомовної взаємодії між усіма учасниками курсу); комунікативний (обмін інформацією) (І. Ковалинська) [7].

Формування фонетичної компетентності студентів вищих навчальних закладів здійснюється в межах відібраного мінімуму за принципом нормативності вимови, це означає, що студенти оволодівають слухо-вимовними та ритміко-інтонаційними навичками, враховуючи вимовну норму іноземної мови, а також підтримують функціонування зазначених навичок на необхідному рівні та здійснюють постійний самоконтроль процесу фонетичного оформлення мовлення (А. Долина) [2]. Західні вчені вважають, що формування фонетичної компетентності $\epsilon$ ефективним, якщо наявна система голосового зв' язку (автономна або інтегрована в систему Moodle) [11].

Дистанційний курс розроблено на платформі Moodle ДВНЗ «Донбаський державний педагогічний університет» i розраховано на вісім тем, кожна тема вивчається впродовж одного тижня. Розпочинається курс із розділу «Загальне», який містить карту вивчення дисципліни, інформацію про авторів курсу, форум взаємодопомоги, навчальну і робочу програму курсу. Карта вивчення дисципліни створена у сервісі Coggle (https://coggle.it) у вигляді блок-схеми й висвітлює теми курсу, відповідно до навчальної програми, типи завдань до кожної теми, основні компетентності, які мають бути сформовані під час навчання в курсі (рис. 1). Coggle $\epsilon$ безкоштовним сервісом і зручним інструментом, який дозволяє створювати карти пам'яті (MindMap). Перевагами сервісу Coggle $\epsilon$ простий інтерфейс, можливість додавання зображень і зберігання готової схеми в кількох форматах (PDF, PNG).

На першій сторінці кожного тижневого завдання подається блок-схема, що графічно висвітлює зміст роботи, враховуючи цілі заняття. Цілі визначено, спираючись на таксономію Б. Блума, у якій передбачено шість рівнів формування навичок критичного мислення - рівні знань, розуміння, застосування, аналізу, синтезу та оцінки [6, с. 88-95]. У курсі «Практична фонетика німецької мови» ці рівні адаптовано до специфіки навчальної дисципліни (див. рис. 2), упорядкування навчальних цілей надає студентам чіткі інструкції щодо організації навчальної діяльності й об'єктивного оцінюваггя досягнутих результатів. 


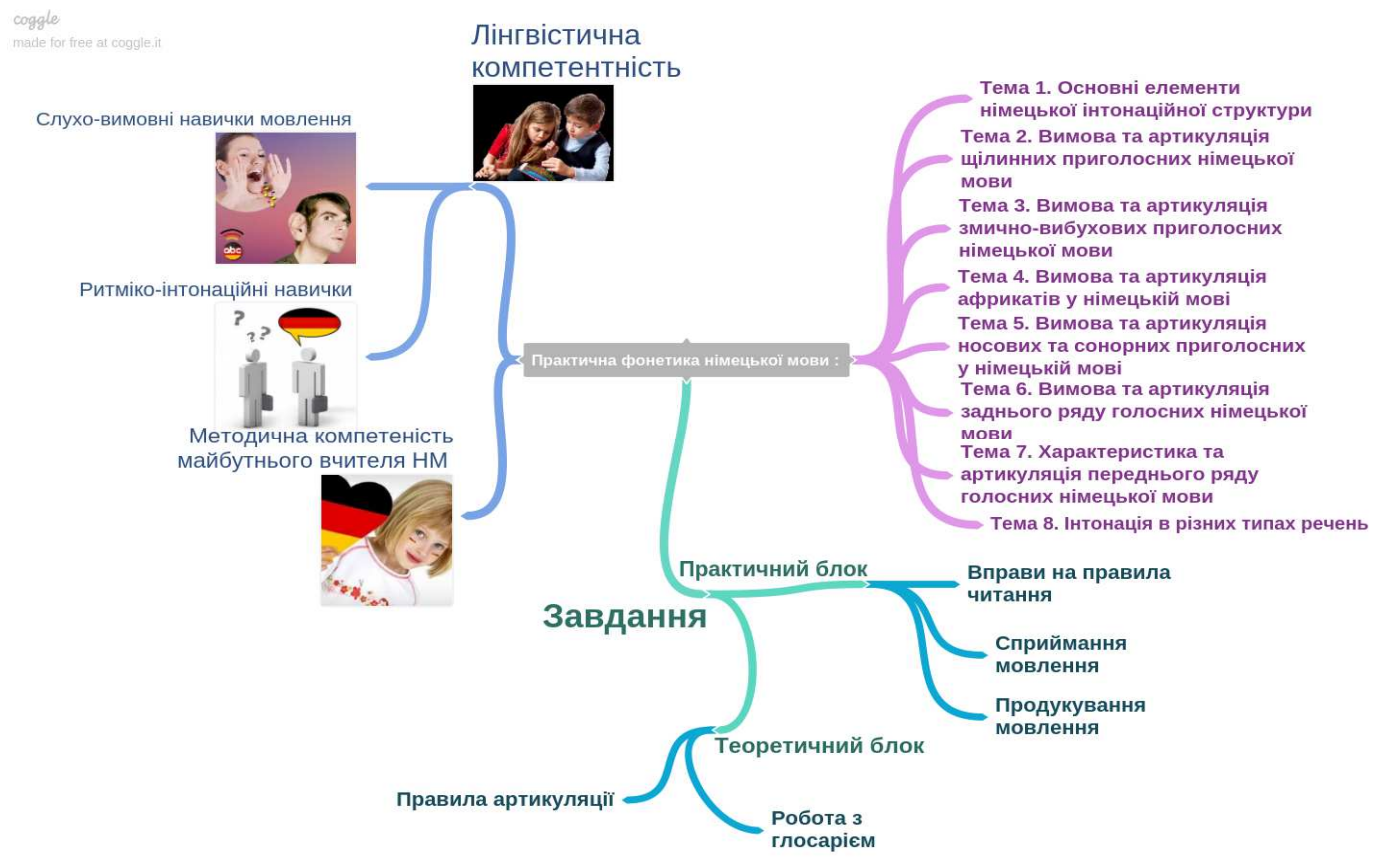

Рис. 1. Карта вивчення навчальної дисципліни «Практична фонетика німецької мови»

Відповідно до визначених цілей розроблено блок завдань, які студенти виконують, щоб досягти очікуваних результатів. Передусім вивчення фонетичного матеріалу студентами передбачає ознайомлення 3 теоретичними відомостями про фонетичне явище, будову артикуляційного апарату, які вводяться на початку кожної теми. Теоретичний блок створено за допомогою послуги «Урок», яка дозволяє логічно структурувати матеріал, представивши його у вигляді HTML-сторінок 3 активними гіперпосиланнями на глосарій курсу. Кожне питання теоретичного блоку візуалізується за допомогою фонетично-орфографічних схем, схем 3 інтонограмами, таблиць, малюнків, на яких зображено артикуляційний апарат тощо (рис. 3).

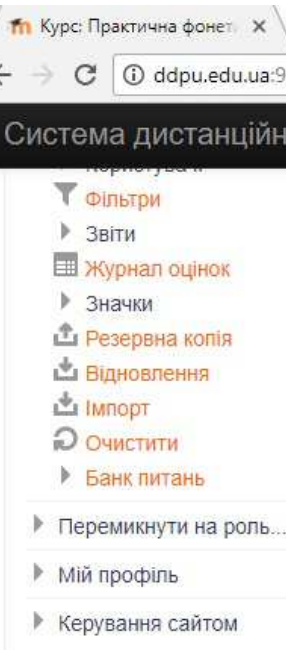

\footnotetext{
> звіти

Е журнал оцінок

1 Значки

ثै Резервна копія

屯 відновлення

山 Imпорт

D очистити

1 Банк питань

- Перемикнути на роль.

1 Мій профіль

1 Керування сайтом
}

Фільтри

Система дистанційного навчання здобувачів вищої освіти

Тема 1. Основні елементи німецької інтонаційної структури

Мета:

рівень знання - характеризувати місце, мету завдання курсу практичної фонетики німецької мови, будову мовного апарату, утворення та сприйняття голосних і приголосних звуків німецької мови:

рівень розуміння - відтворювати алфавіт німецької мови, розрізняти типи складів німецької мови (відкриті, закриті, умовно закриті), встановлювати графемнофонемні та фонемно-графемні зв'язки:

рівень застосування - ілюструвати уміння та навички читання із дотриманням правил читання, правильно розставляти наголос в слові та реченні;

рівень аналізу - на основі правильного наголошення слів та речень аналізувати правильну вимову та інтонування простих розповідних речень, питальних речень з питальним словом:

рівень синтезу - добирати приклади простих розровідних речень та питальних речень 3 питальним словом, скласти інтонограму до кожного із них,

рівень оиінювання - відтворювати за диктором уривки тексту, дотримуючись правил читання та інтонування.

Рис. 2. Визначення иілей за таксономією Б. Блума 
Працюючи 3 теоретичним конвентом, ми керувалися такими принципами (за В. Кухаренком):

- мінімізації - курс має практичну спрямованість, тому теоретичний матеріал подається стисло з невеликою кількістю сторінок;

- однотипових форматів - використання одного формату і шрифту сторінки, що полегшує роботу із сервісом і робить його більш естетичним;

- однотипової навігації - список меню охоплює всі сторінки теоретичного блоку, на кожній сторінці $є$ посилання на повернення до головної сторінки, а також попередньої і наступної в кожному блоці [6].

У курсі до кожного теоретичного блоку викладач подає відеолекцію, яка повністю відповідає тематиці заняття і розроблена не автором курсу, а спеціалістами (носіями мови) в галузі лінгвістики з Німеччини, така відеофонограма є еталоном для імітування мовлення.

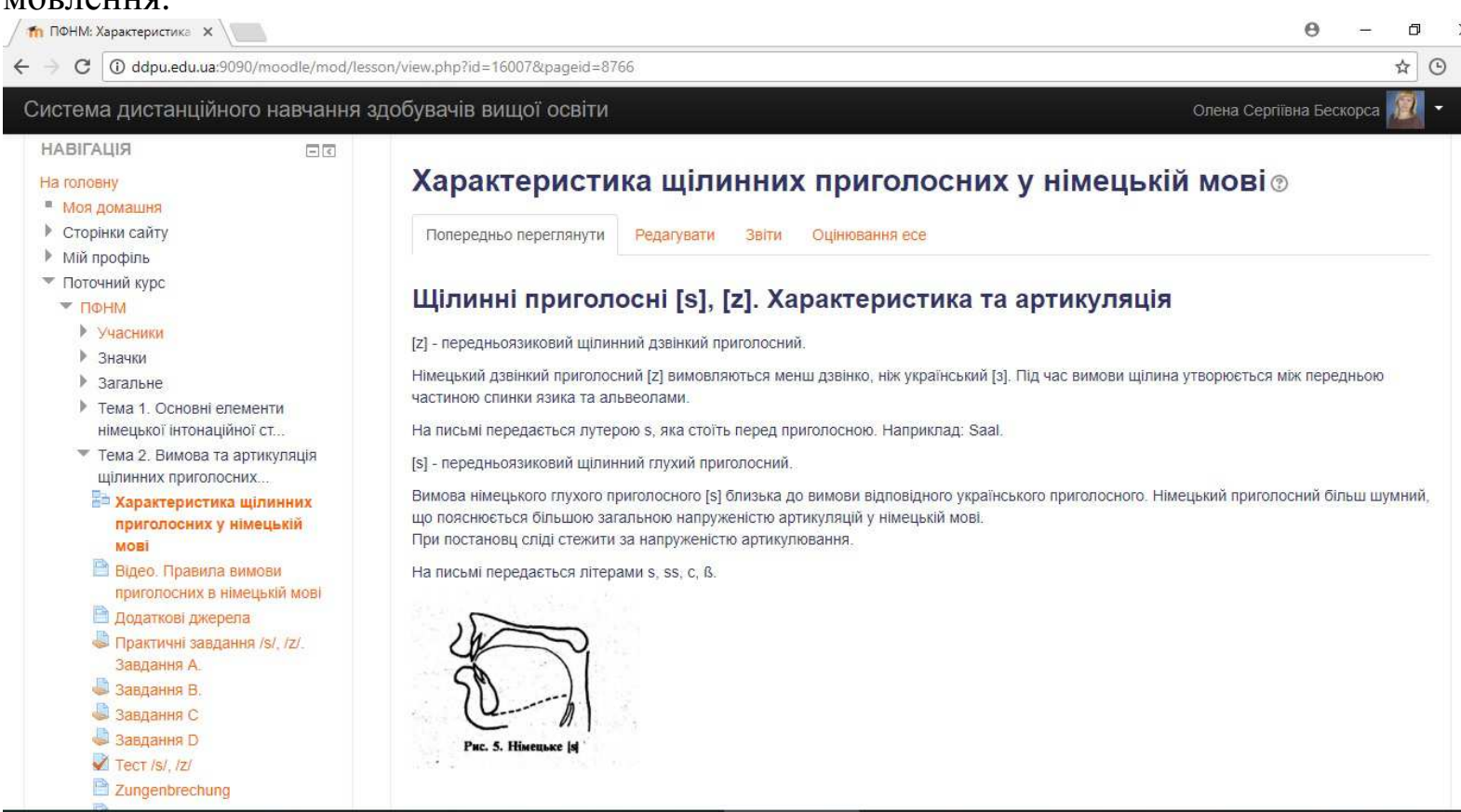

Рис. 3. Теоретичні основи вивчення вимови щілинних приголосних. Фрагмент сторінки теоретичного блоку

Під час опрацювання теоретичного блоку студенти виконують завдання в ресурсі «Глосарій», які мають на меті поглибити теоретичні знання шляхом збирання та систематизації інформації з різних джерел. Наприклад, на першому вступному занятті «Основні елементи німецької інтонаційної структури» студентам запропоновано опрацювати такі поняття: фонетична моторика, парафонетична моторика, фразова акцентуація, просодія, синтагма, акцентна (ритмічна) група, спадний тон, висхідний тон. У цьому завданні студентам заборонено редагувати визначення, але дозволено коментувати поняття, за кожен коментар студенти отримують додаткові бали. У коментарях вони можуть розширювати наявні визначення, додавати приклади слів, речень, інтонограм тощо.

Засвоївши теоретичні знання, здійснюється перехід до формування практичних слухо-вимовних і ритміко-інтонаційних навичок. К. де Брейн (Ch. de Bruijn), М. Б. Нунс (M. B. Nunes)y дистанційному курсі 3 практичної фонетики англійської мови пропонують два етапи формування навичок: транскрипція і продукція [12]. На першому етапі транскрипції вони застосовують систему вправ, створену за допомогою ресурсу «Тест» із завданнями на транскрибування окремих фонем, слів, коротких фраз, а також 
слів-нонсенсів. Слова-нонсенси $\epsilon$ важливою складовою уміння встановлювати графемно-фонемні і фонемно-графемні зв'язки. У вправах на транскрипцію окремих слів вони пропонують студентам обирати, які саме фонеми мають бути включені до вправ - приголосні (щілинні, сонорні, змично-вибухові тощо) або голосні (переднього ряду, заднього ряду, лабіалізовані, монофтонги, дифтонги тощо). Також студенти можуть обирати між односкладовими, двоскладовими або багатоскладовими словами, цей вибір може бути випадковим, коли електронний ресурс сам обирає, з яких фонем будуть складатися слова та їх кількість. П. Лейдфоджд (P. Ladefoged) стверджує, що транскрибуючи слова 3 контексту, студенти здогадуються про значення певних фонем. Слова-нонсенси допомагають мінімізувати механізми мовної здогадки і максимально зосередитися на фонетичному боці слова [12].

Учені одностайні у своїх твердженнях, що транскрибування слів не дає об'єктивної оцінки всіх наявних артикуляційних умінь, однак $є$ необхідним на початковому етапі вивчення англійської мови. Транскрипція в навчанні німецької мови не має такого важливого значення, як в англійській мові, тому що більшість німецьких букв мають постійні звукові відповідності. Тому, фокусуючи увагу в дистанційному курсі на практичних навичках спілкування в усіх видах мовленнєвої діяльності, ми виключили вправи на транскрибування, однак додали завдання на артикуляцію та сприйняття на слух в практичному блоці. Ці вправи не суперечать другому етапу (продукціï) дистанційного курсу К. де Брейна (Ch. de Bruijn) i $\quad$ М. Б. Нунса (M. B. Nunes).

У дистанційному курсі «Практична фонетика німецької мови» ми розділяємо думку багатьох сучасних українських методистів (Н. Бориско, С. Ніколаєва, С. Роман та ін.), що фонетичні вправи не можуть бути суто репродуктивними або продуктивними. Перед тим як студенти зможуть відтворювати фонеми й інтонеми, вони повинні мати змогу прослухати зразок мовлення. Тому ми надаємо перевагу рецептивно-(ре)продуктивним вправам, які реалізують дві цілі - формування слухових та вимовних навичок [2]. Реалізації такого підходу сприяють мультимедійні засоби, які легко інтегруються в Moodle. 3-поміж ресурсів платформи Moodle (HotPotatoesQuiz, SCORM/AICC, Wiki, База даних, Веб-сторінка, Глосарій, Завдання - відповідь 3 прикріпленням файлів - текстових або аудіофайлів, Лекція, Семінар, Тест, Форум, Чат) у курсі практичної фонетики німецької мови переважно використовується Завдання, Веб-сторінка, Тест. Послідовність формування слухо-вимовних та ритмікоінтонаційних навичок $є$ лінійною в межах однієї теми - спочатку формуються рецептивні і рецептивно-репродуктивні, а потім продуктивні навички.

Практичний блок починається з вправ на відпрацювання вимови і правил читання, оформлених у ресурсі «Завдання», студентам пропонується прослухати і повторити за диктором окремі слова, пари слів із контрастними звуками, короткі речення й невеликі тексти. Свої відповіді вони мають прикріплювати у вигляді аудіофайлів, автор курсу пропонує студентам відео-інструкції у вигляді Веб-сторінки про створення звукозаписів на різних пристроях і на різних операційних системах. Враховуючи технічні особливості електронної освітньої платформи Moodle, в інструкціях до практичних завдань пропонують студентам записувати власне мовлення і потім завантажувати ці аудіофайли до платформи. Однак кожен курс має загальний обмежений обсяг (2 Гб) і обсяг окремого файлу (2 Мб), тому навчальні матеріали можуть бути розміщені на хмаро-орієнтованому сервісі Google Диск, надавши викладачеві доступ до них.

Ресурс «Завдання» $є$ зручним сервісом для виконання фонетичних вправ. Система дозволяє викладачеві встановити термін виконання завдання, кількість прикріплювальних файлів i їх обсяг, виставити оцінку за виконання вправи або 
повернути завдання на доопрацювання, додавши коментар. Після виконання цих завдань студенти проходять тестування. Для вдосконалення слухових навичок, завдання до тесту також містять аудіофайли, прослухавши які, слід додати пропущену літеру в слові, обрати слова, які промовлялися диктором або доповнити слова в тексті. Для розроблення тестів було використано ресурси - тест множинного вибору або 3 вбудованою відповіддю.

Методисти одностайні у своїх твердженнях, що закріплення мовних (фонетичних) навичок має проходити під час здійснення мовленнєвої діяльності. Попри це, формування фонетичних навичок в умовно-комунікативних або комунікативних вправах сприяє вдосконаленню лексичних i граматичних навичок: вправи на формування слухо-вимовних навичок охоплюють певну кількість лексичних одиниць, робота над формуванням ритміко-інтонаційних навичок актуалізує знайому лексику i граматичні структури на рівні фрази або понадфразової єдності. Слід зауважити, що початковий рівень вивчення німецької мови не вимагає володіння лексикограматичним матеріалом на рівні довершених навичок. Ступінь володіння мовними й мовленнєвими навичками може різнитися, однак, необхідно прагнути того, щоб у кожне заняття були інтегровані завдання, які збагачують мовленнєвий досвід студентів на максимально високому рівнів заданих умовах [4, с. 352-353]. Тому в кінці кожної теми розміщено комунікативний блок, який складається 3 вправ на формування комунікативної компетентності в аудіюванні, читанні вголос та говорінні.

Кожна 3 восьми тем містить завдання на аудіювання, створені в ресурсі «Завдання», доповнені аудіозаписами або посиланнями на навчальні відеофільми. Окрім вправ на розвиток фонетичних навичок (визначення меж синтагм, інтонаційного оформлення речень, складання інтонограм), студенти виконують тестові завдання (заповнення пропусків у тексті, множинне зіставлення, кросворди) для перевірки розуміння прослуханого.

Завдання на читання вголос - записати аудіоказку для учнів початкової школи мають на меті, по-перше, перевірити правильність оформлення власного мовлення, подруге, збагатити методичне портфоліо студентів ресурсами, які вони зможуть використовувати на уроках німецької мови в початковій школі під час практичної підготовки або власної професійної діяльності.

Електронна освітня платформа Moodle має обмежений спектр можливостей щодо розвитку вмінь говоріння. Ми пропонуємо студентам зробити аудіозапис власного мовлення і завантажити його до платформи. Слід відзначити, що саме під час говоріння можна визначити рівень сформованості слухо-вимовних i ритміко-інтонаційних навичок, зокрема правильність вимови окремих звуків, слів, оформлення мовленнєвого дихання, наголос у словах, фразовий наголос, поділ речення на синтагми, зв'язування ненаголошених слів із наголошеними тощо.

У нашому досліджені окреслено можливості організації змішаного навчання дисципліни «Практична фонетика німецької мови» у віртуальному навчальному середовищі Moodle, окреслюючи типи вправ i pecypciв Moodle, яким надається перевага під час формування слухо-вимовних і ритміко-інтонаційних навичок студентів напряму підготовки «Початкова освіта» в ДВНЗ «Донбаський державний педагогічний університет».

\section{4. ВИСНОВКИ ТА ПЕРСПЕКТИВИ ПОДАЛЬШИХ ДОСЛІДЖЕНЬ}

Ефективність впровадження дистанційного курсу відбувалася через експериментальну перевірку рівня сформованості фонетичної компетентності, iii рецептивної і продуктивної складової, під час виконання контрольних зрізів у таких 
видах мовленнєвої діяльності як аудіювання та говоріння серед студентів другого i третього курсів, спеціальності «Початкова освіта». Студенти третього курсу (контрольна група - КГ - 12 осіб) навчалися за традиційною методикою формування фонетичної компетентності, студенти другого курсу (експериментальна група - ЕГ - 14 осіб) навчалися за технологією змішаного навчання, під час якої частину навчального матеріалу студенти опрацьовували на аудиторних заняттях, а іншу частину матеріалу засвоювали в дистанційному курсі.

Критеріями для визначення рівня сформованості слухо-вимовних ритмікоінтонаційних навичок були: 1) паузація; 2) інтонація різних типів речення; 3) швидкість і правильність мовлення. Паузацією в аудіюванні й говорінні вимірюється рівень сформованості навички визначення меж синтагм і речень. За другим критерієм оцінюється навичка визначення типу речення на слух (в аудіюванні) і правильного інтонаційного оформлення різних типів речень (у говорінні). Оцінювання за третім критерієм проводиться за такими параметрами: сприйняття i розуміння мовлення (аудіювання), швидкість мовлення, чіткість вимови звуків, кількість хезитаційних пауз та їх тривалість (говоріння).

Обчислення кожного критерію здійснюється за 20-бальною шкалою. Максимальна кількість балів за всіма критеріями - 60 балів.

Передекспериментальний зріз проводився після вивчення першої теми «Основні елементи німецької інтонаційної структури», його середні результати на одного студента були такими: КГ - 24,6 балів, ЕГ - 23,8 балів. Післяекспериментальний зріз проводився після вивчення всіх восьми тем навчальної дисципліни «Практична фонетика німецької мови» і його результати були такими: КГ - 30,4 балів, ЕГ - 42,1 балів. Порівняльні дані по кожній із двох груп представлені в діаграмі 1.

Діаграма 1

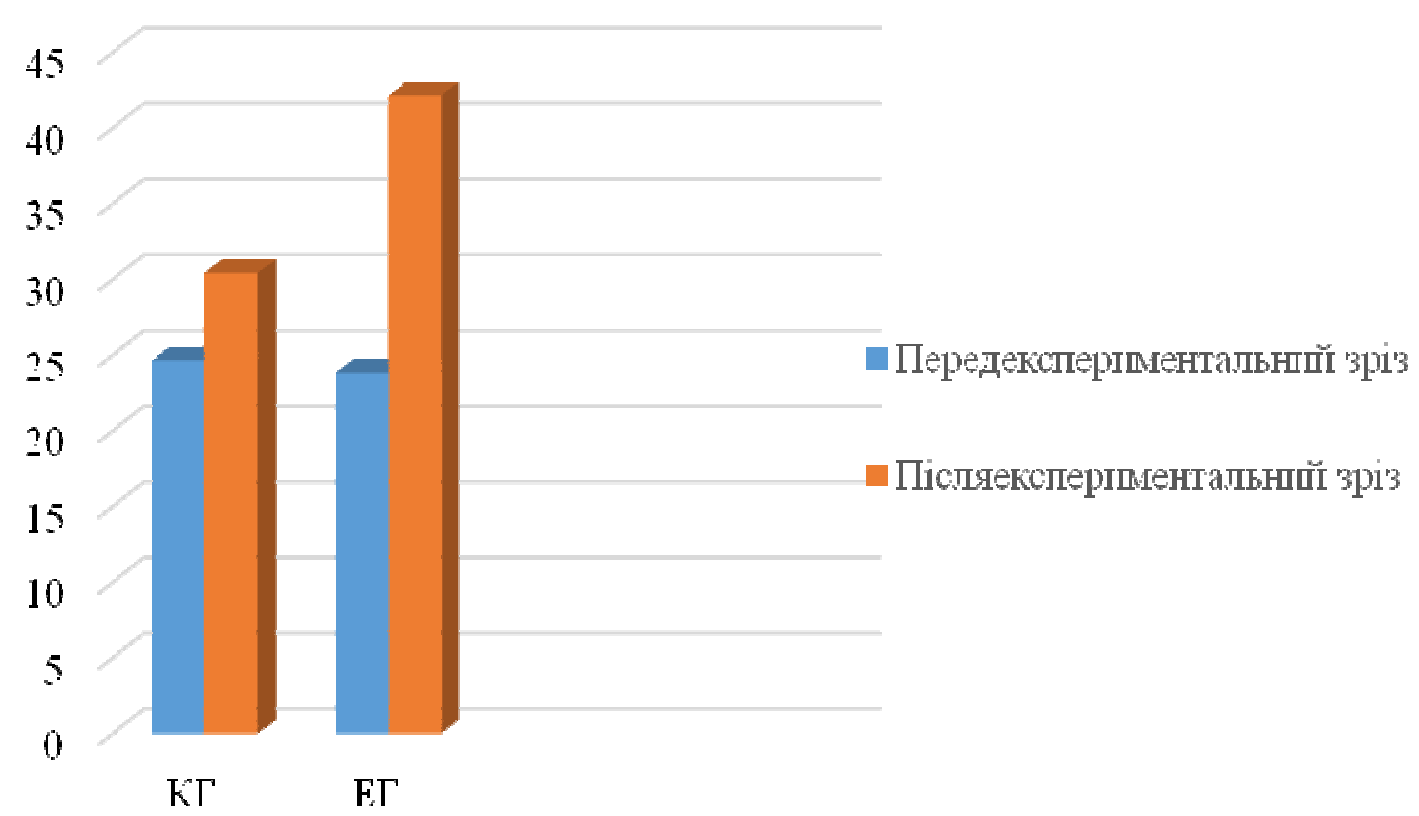

Діаграма 1. Результати експериментальної перевірки ефективності організації зміманого навчання з навчальної дисцилліни «Практична фонетика німецької мови»

Отже, одержані результати експериментальної перевірки дають нам підставу стверджувати, що організація змішаного навчання за розробленим нами дистанційним курсом «Практична фонетика німецької мови» $\epsilon$ ефективною. Послідовність опрацювання навчальних блоків (теоретичного, практичного, комунікативного), 
надавання переваги завданням із використанням системи автономного голосового зв’язку забезпечують високий рівень сформованості в студентів слухо-вимовних ритміко-інтонаційних навичок.

На нашу думку, перспективною в подальших дослідженнях $є$ вивчення можливостей інтегрованого плагіну PoodLL, який є засобом голосового зв'язку в системі Moodle, а також визначення специфіки вправ у віртуальному навчальному середовищі 3 курсу «Практика усного та писемного мовлення (німецька мова)», вивчення якого розпочинається після опанування вступного фонетичного курсу.

\section{СПИСОК ВИКОРИСТАНИХ ДЖЕРЕЛ}

[1] Н. Бориско, “Методика формування іншомовної фонетичної компетенції”, Іноземні мови, № 3, с. 3-14, 2011.

[2] А. В. Долина, “Особливості процесу вдосконалення фонетичної компетенції майбутніх учителів іноземної мови”, у Якість вищої мовної освіти: иляхи вдосконалення організації і проведення педагогічної практики студентів-філологів, О. В. Рафієнко, Ред. Горлівка, Україна: Вид-во ГДПІІМ, 2009, с. 230-234.

[3] А. Хомутова, “Фонетическая компетенция: структура, содержание”, Вестник Южно-Уральского государственного университета. Серия: Лингвистика, № 2(10), с. 71-76, 2013.

[4] О. Старинець, О. Гуслистий,“Формування навичок вимови на початковому етапі навчання другої іноземної мови у студентів напряму підготовки “Туризм”, Гуманітарна освіта у технічних вищих навчальних закладах, № 28, с. 346-355, 2013. [Електронний ресурс]. Доступно:http://jrnl.nau.edu.ua/index.php/go/article/view/8088. Дата звернення: Лип. 12, 2017.

[5] А. М. Аврамчук, “Огляд додатків системи Moodle для проектування мультимедійних електронних освітніх ресурсів з мовних дисциплін”, Інформаційні технології і засоби навчання,№ 4(48), с. 103121, 2015. [Електронний ресурс]. Доступно: http://journal.iitta.gov.ua/index.php/itlt/article/view/1264/942.Дата звернення: Серп. 31, 2017.

[6] В. М. Кухаренко та ін., Теорія та практика змішаного навчання, Харків, Україна: «Міськдрук», НТУ «ХПІ», 2016.

[7] I. В. Ковалинська, “Можливості використання електронного навчального простору”,Вісник Чернігівського національного педагогічного університету. Серія: Педагогічні науки, вип. 101, с. 159-162, 2012.

[8] Є. В. Долинський, "Можливості використання навчального середовища Moodle при вивченні іноземної мов та перекладу”, Збірник наукових працьь Хмельницького інституту соиіальних технологій Університету «Україна», № 1, с. 82-85, 2013 . [Електронний ресурс]. Доступно: http://nbuv.gov.ua/UJRN/Znpkhist_2013_1_20. Дата звернення: Серп. 17, 2017.

[9] А. О. Томіліна, "Можливості розробок електронних освітніх ресурсів на базі електронної платформи Moodle під час навчання студентів іноземної мови”, Педагогіка вищої та середньої школи, № 46, с. 225-230, 2015. [Електронний ресурс]. Доступно: http://nbuv.gov.ua/UJRN/PVSSh_2015_46_43. Дата звернення: Лип. 27, 2017.

[10] N., Maiier,"Distance learning technologies in organizing self-study work of students majoring in philology”, Інформаційні технології $і$ засоби навчання, № 3(59), с. 96-102, 2017. [Електронний peсурс]. Доступно: http://journal.iitta.gov.ua/index.php/itlt/article/view/1651/1194. Дата звернення: Лип. 14, 2017.

[11] M. Ashby, K. Yanagisawa, Y. S. Kim, J. Maidment, and J. Przedlacka, "Achieving interactivity in online learning of phonetic skills". Phonetics Teaching andLearning Conference, London, 2009, pp. 368-371.

[12] Ch. de Bruijn, M. B. Nunes, L. Fang, R. Pathak, and J. Zhou, "A system for independent e-learning of practical phonetics”, 17th International Congress of Phonetic Sciences, Hong Kong, 2011, pp. 368-371.

[13] К. Л. Бугайчук, “Змішане навчання: теоретичний аналіз та стратегія впровадження в освітній процес вищих навчальних закладів”, Інформаційні технології $і$ засобинавчання, № 4(54), с. 1-18, 2016. [Електронний ресурс]. Доступно: http://journal.iitta.gov.ua/index.php/itlt/article/view/1434/1070. Дата звернення: Серп. 29, 2017.

[14] Л. Н Пузейкина, В. Б. Ребриков, “Перспективы интеграции классических форм обучения иностранному языку в систему електронного обучения Moodle: вводный фонетический курс немецкого языка", CredeExperto: mpaнспорт, общество, образование, язык, № 1(06), с. 1-19, 2014. 


\title{
СИСТЕМА МООDLЕ КАК СРЕДСТВО ОРГАНИЗАЦИИ СМЕШАННОГО ОБУЧЕНИЯ ПРАКТИЧЕСКОЙ ФОНЕТИКЕ НЕМЕЦКОГО ЯЗЫКА
}

\author{
Бескорсая Елена Сергеевна \\ кандидат педагогических наук, \\ старший преподаватель кафедры теории и практики начального образования \\ ГВУЗ «Донбасский государственный педагогический университет», г. Славянск, Украина \\ ORCID ID 0000-0001-8018-8549 \\ beskorsyhelen@gmail.com
}

\begin{abstract}
Аннотация. В статье речь идет об организации смешанного обучения дисциплины «Практическая фонетика немецкого языка» в виртуальной образовательной среде Moodle. Автор обобщает передовой опыт отечественных и западных исследователей по вопросам внедрения смешанного обучения и технологии разработки дистанционных курсов в виртуальной образовательной среде Moodle. Отмечено, что специфика упражнений в курсе практической фонетики заключается в том, что они должны содержать задания на запись собственного голоса, для оценки уровня сформированности слухо-произносительных и ритмико-интонационных навыков речи. Автор описывает собственный опыт внедрения дистанционного курса в обучение фонетики студентов специальности «Начальное образование». Предложенный автором курс содержит восемь тем, каждая тема предполагает выполнение заданий в трех блоках - теоретическом, практическом, коммуникативном. В статье представлены данные экспериментальной проверки внедряемого курса, которые подтверждают его эффективность.
\end{abstract}

Ключевые слова: практическая фонетика; немецкий язык; фонетическая компетентность; ритмико-интонационные навыки; слухо-произносительные навыки; виртуальная образовательная среда; Moodle; смешанное обучение.

\section{VIRTUAL LEARNING ENVIRONMENT MOODLE AS A MEANS TO ORGANIZE BLENDED LEARNING IN TEACHING PRACTICAL PHONETICS OF GERMAN LANGUAGE}

\author{
Olena S. Beskorsa \\ $\mathrm{PhD}$ (Pedagogical Sciences), Senior Lecturer of Primary Education Theory and Practice Department \\ SHEE “Donbas State Pedagogical University”, Slovyansk, Ukraine \\ ORCID ID 0000-0001-8018-8549 \\ beskorsyhelen@gmail.com
}

\begin{abstract}
In the article the problem of organizing blended learning of the course "Practical phonetics of German language" by means of virtual learning environment Moodle is revealed. The author summarizes the best practices of native and foreign researchers on the issues of blended learning implementation and technology of designing distance courses in the virtual learning environment Moodle. It is noted that the specificity of exercises in the course of practical phonetics is in the fact that they should contain tasks for recording their own voice to assess the level of formation of listening and pronunciation, rhythmic and intonation skills. The author describes his own experience in implementing the distance course in teaching the phonetics to students of the specialty "Primary Education". The course offered by the author covers eight themes; each theme assumes the fulfillment of tasks in three blocks - theoretical, practical, and communicative. The article presents data of experimental verification of the implemented course that confirm its effectiveness.
\end{abstract}

Key words: practical phonetics; the German language; phonetic competence; listening and pronunciation skills; rhythmic and intonation skills; virtual learning environment; Moodle; blended learning. 


\section{REFERENCES (TRANSLATED AND TRANSLITERATED)}

[1] N. Borysko, "Methodology of forming foreign language phonetic competence", Foreign Languages, \# 3, pp. 3-14, 2011. (in Ukrainian)

[2] A. V. Dolyna, "Peculiarities of the process of improving future foreign language teachers' phonetic competence", in The quality of higher language competence: ways of improving organizing and conducting students' pedagogical practice, O. V. Rafiienko, Eds. Horlivka, Ukraine: Vydavnytstvo HDPIIM, 2009, pp. 230-234. (in Ukrainian)

[3] A. Khomutova, "Phonetic competence: structure, content", Bulletin of South Ural State University. Series: Lingustics, \# 2(10), pp. 71-76, 2013.(in Russian)

[4] O. Starynets, O. Huslystyi, "Forming pronunciation skills of Tourism students at the initial level of learning the second foreign language", Humanitarian Education in Technical Universities, \#28, pp. 346355, 2013. [Online]. Available:http://jrnl.nau.edu.ua/index.php/go/article/view/8088. Accessed on:July 12, 2017. (in Ukrainian)

[5] A. M. Avramchuk, "An overview of the Moodle system applications for designing multimedia electronic educational resources for language disciplines", Information technologies and learning tools, \# 4(48), pp. 103-121, 2015. [Online].

Available: http://journal.iitta.gov.ua/index.php/itlt/article/view/1264/942.Accessed on: Aug. 31, 2017. (in Ukrainian)

[6] V. M. Kukharenko et al., Theory and practice of blended learning, Kharkiv, Ukraine: "Miskdruk", NTU "KhPI", 2016. (in Ukrainian)

[7] I. V. Kovalynska, "Possibilitiesof using e-learning space", Bulletin of Chernihiv national pedagogical university. Series: Pedagogical sciences, \# 101, pp. 159-162, 2012. (in Ukrainian)

[8] Ye. V. Dolynskyi, " Possibilities of using Moodle learning environment while learning foreign language and translation”, Proceedings of Khmelnytsky Institute of Social Technologies University “Ukraine”, \#1, pp.82-85, 2013. [Online]. Available: http://nbuv.gov.ua/UJRN/Znpkhist_2013_1_20. Accessed on: Aug. 17, 2017. (in Ukrainian)

[9] A. O. Tomilina, "Possibilities of designing electronic educational resources on the basis of electronic platform Moodle while training students' foreign language training",Pedagogics of higher and secondary school,\# 46, pp. 225-230, 2015. [Online]. Available: http://nbuv.gov.ua/UJRN/PVSSh_2015_46_43.Accessed on: Jul. 27, 2017. (in Ukrainian)

[10] N. Maiier, "Distance learning technologies in organizing self-studywork of students majoring in philology",Information technologies and learning tools, \# 3(59), pp. 96-102, 2017. [Online]. Available: http://journal.iitta.gov.ua/index.php/itlt/article/view/1651/1194.Accessed on: Jul. 14, 2017. (in English)

[11] M. Ashby, K. Yanagisawa, Y. S. Kim, J. Maidment, and J. Przedlacka, "Achieving interactivity in online learning of phonetic skills”. Phonetics Teaching and Learning Conference, London, 2009, pp. 368-371. (in English)

[12] Ch. de Bruijn, M. B. Nunes, L. Fang, R. Pathak, and J. Zhou, "A system for independent e-learning of practical phonetics", 17th International Congress of Phonetic Sciences, Hong Kong, 2011, pp. 368-371. (in English)

[13] K. L. Buhaichuk, "Blended learning: theoretical analysis and strategy of implementing into the educational process at tertiary institutions", \# 4(54), pp. 1-18, 2016. [Online]. Available: http://journal.iitta.gov.ua/index.php/itlt/article/view/1434/1070. Accessed on: Aug. 29, 2017. (in Ukrainian)

[14] L. N. Puzeykina, V. B. Rebrikov, Prospects for integration of classical forms of foreign language teaching in e-learning system Moodle: introduction to German phonetics, Crede Experto:transport, society, education, language, \#1(06), pp. 1-19, 2014. (in Russian)

\section{$($ Cc) BY-NC-SA}

This work is licensed under Creative Commons Attribution-NonCommercial-ShareAlike 4.0 International License. 